\title{
DAMPAK PERUBAHAN IKLIM TERHADAP USAHATANI PADI DI DESA WANGUK KECAMATAN ANJATAN KABUPATEN INDRAMAYU
}

\section{IMPACT OF CLIMATE CHANGE ON PADDY FARMING IN WANGUK VILLAGE ANJATAN SUBDISTRICT INDRAMAYU DISTRICT}

\author{
Getmi Nuraisah*, Rani Andriani Budi Kusumo \\ Fakultas Pertanian Universitas Padjadjaran \\ Jalan Raya Bandung - Sumedang KM 21 Sumedang 45363 \\ *Corresponding email: gnuraisah@gmail.com \\ (Diterima 22-10-2018; Disetujui 07-01-2019)
}

\begin{abstract}
ABSTRAK
Salah satu ancaman terbesar dalam dunia pertanian adalah terjadinya perubahan iklim global yang kemungkinan dapat mengakibatkan kegagalan panen. Pertanian dan perubahan iklim mempunyai kaitan yang sangat erat karena sektor pertanian sangat bergantung dan sangat rentan terhadap perubahan iklim, sehingga pengetahuan petani dalam menghadapi perubahan iklim sangat diperlukan. Penelitian ini bertujuan untuk mengkaji sejauh mana pengetahuan petani terhadap perubahan iklim yang sedang terjadi serta dampak yang ditimbulkan oleh perubahan iklim, khususnya pada tanaman padi. Penelitian ini dilakukan dengan menggunakan desain kualitatif dengan teknik studi kasus, dengan menggunakan data primer dan sekunder. Penentuan informan dilakukan secara purposif yaitu petani yang telah melakukan usahatani \pm selama 10 tahun yang mengalami gagal panen dan yang tidak dengan status kepemilikan lahan mereka. Teknik pengumpulan data yang digunakan berupa observasi, wawancara dan studi literatur. Rancangan analisis data menggunakan analisis deskriptif. Hasil penelitian menunjukkan bahwa petani yang mengalami gagal panen maupun yang berhasil panen sudah mengetahui dan merasakan perubahan yang terjadi seperti perubahan masa tanam, perubahan suhu, perubahan curahan hujan, cuaca ekstrim, dan serangan OPT, tetapi petani belum dapat menjelaskan apa perubahan iklim itu sendiri. Dampak yang dirasakan petani akibat perubahan iklim yang terjadi yaitu petani mengalami penurunan hasil panen, meningkatnya serangan OPT, peningkatan risiko gagal panen dan penurunan pendapatan petani.
\end{abstract}

Kata kunci: Iklim, Petani, Padi, Dampak

\begin{abstract}
One of the biggest threats in the world of agriculture is the occurrence of global climate change which is likely to result in crop failure. Agriculture and climate change have a very close connection, because agricultural sector is very dependent and very vulnerable to climate change, so that the knowledge of farmers in the magnitude of climate change is needed. This study aims to examine the extent to which farmers' knowledge of climate change is happening and the impacts caused by climate change, especially on rice. This research was carried out using qualitative design with "case study" techniques, using primary data and secondary data. Determination of informants was carried out purposively, namely farmers who had done farming for \pm 10 years who experienced crop failure and who were not with their land ownership status. Data collection techniques used in the form of observation, interviews and literature studies. The design of data analysis uses descriptive analysis. The results of this study indicate that farmers who experience crop failure and who have harvested already know and feel the changes that occur such as changes in planting, changes in temperature, changes in rainfall, extreme weather, and pest attacks, but farmers have not been able to explain what climate change own. The impact felt by farmers due to
\end{abstract}


DAMPAK PERUBAHAN IKLIM TERHADAP USAHATANI PADI

DI DESA WANGUK KECAMATAN ANJATAN KABUPATEN INDRAMAYU

Getmi Nuraisah, Rani Andriani Budi Kusumo

climate change is that farmers experience a decline in yields, increased pest attacks, increased risk of crop failure and a decrease in farmers' income.

Keywords: Climate, Farmers, Rice, Impact

\section{PENDAHULUAN}

Pemanasan global merupakan isu lingkungan yang dapat menyebabkan perubahan iklim global. Perubahan iklim global terjadi secara perlahan dalam jangka waktu yang cukup panjang, yaitu antara 50-100 tahun. Meskipun terjadi secara perlahan, perubahan iklim memberikan dampak yang sangat besar terhadap kehidupan. Perubahan iklim juga berdampak terhadap kenaikan frekuensi maupun intensitas kejadian cuaca ekstrim, perubahan pola hujan, serta peningkatan suhu dan permukaan air laut. Kejadian iklim ekstrim akan menyebabkan beberapa hal, diantaranya: (a) kegagalan panen dan tanam, yang berujung pada penurunan produktivitas dan produksi; (b) kerusakan sumberdaya lahan pertanian; (c) peningkatan intensitas banjir/kekeringan; (d) peningkatan kelembaban; dan peningkatan intensitas organisme pengganggu tanaman (Estiningtyas et al. 2012).

Salah satu sektor yang terpengaruh adanya perubahan iklim adalah sektor pertanian. Besarnya dampak perubahan iklim terhadap sektor pertanian bergantung pada tingkat dan laju perubahan iklim, serta sifat dan kelenturan sumberdaya dan sistem produksi pertanian. Salah satu komoditas pertanian yang paling terpengaruh dampak dari perubahan iklim adalah padi. Akibat suhu dan kelembaban udara yang semakin meningkat, akan memicu pertumbuhan dan perkembangan organisme pengganggu tanaman. Salah satunya adalah serangan hama wereng cokelat yang terjadi di wilayah pantai utara jawa (pantura) yang mengalami gagal panen selama dua musim tanam. Serangan hama tersebut sedikitnya menyebabkan 4.000 hektar tanaman padi di Kabupaten Cirebon mengalami gagal panen (Radar Cirebon, 2017) ${ }^{1}$. Bukan hanya Cirebon yang mengalami gagal panen akibat perubahan iklim, ratusan hektar area pertanian di Indramayu juga mengalami gagal panen akibat serangan hama bahkan sebagian besar sedang dalam masa panen (Radar Cirebon) $)^{2}$. Berdasarkan pengamatan dari instansi

\footnotetext{
${ }^{1}$ http://www.radarcirebon.com/diserang-werengpetani-cirebon-gagal-panen-selama-duamusim.html (diakses pada 30 January 2018) ${ }^{2}$ http://www.radarcirebon.com/ratusan-hektaretanaman-padi-terserang-opt.html/areal-pertaniandi-indramayu-terkena-hama-meskipun-sebagianlagi-sedang-panen (diakses pada 02 February 2018)
} 
pertanian, hama wereng dapat menyebarkan virus atau penyakit kerdil yang dapat membuat petani mengalami kerugian bahkan gagal panen. Selain itu, ada beberapa jenis hama yang muncul akibat adanya perubahan iklim dan menyerang tanaman padi yaitu tikus dan tungro.

Kabupaten Indramayu merupakan salah satu kabupaten di Provinsi Jawa Barat yang merupakan salah satu daerah utama penghasil padi di Indonesia. Kabupaten/Kota Indramayu merupakan daerah sentra produksi padi terbesar di Jawa Barat pada tahun 2012-2016 dengan rata-rata produksi sebanyak 1.401.811ton (BPS, 2017). Hal tersebut menggambarkan bahwa posisi Kabupaten Indramayu sangat penting dan menjadi nomor satu daerah dengan produksi padi tertinggi di Jawa Barat. Posisi Kabupaten Indramayu yang menjadi daerah dengan produksi padi tertinggi di Jawa Barat, tidak terlepas dari peranan kecamatan atau desa penghasil padi tertinggi di wilayah Indramayu. Dalam hubungannya dengan kabupaten/kota, kecamatan dan desa merupakan hinterland atau daerah pendukung yang berfungsi sebagai penyedia bahan pokok seperti padi, sayur-sayuran, dan lain sebagainya. Kecamatan Anjatan merupakan salah satu daerah penghasil padi terbesar di
Kabupaten Indramayu setelah Gantar dan Kroya, dengan luas lahan sawah 6.100 hektar yang seluruhnya merupakan sawah irigasi dengan rata-rata produksi pada tahun 2012-2016 sebesar 93.313,56 ton.

Kecamatan Anjatan adalah salah satu kecamatan yang mengalami kerugian akibat gagal panen. Beberapa desa yang mengalami gagal panen di Kecamatan Anjatan adalah Lempuyang, Salamdarma, Kopyah, Mangun Jaya, dan Wanguk. Kerugian terbesar akibat gagal panen terjadi di Desa Wanguk, sedikitnya \pm 430 hektar areal persawahan $80 \%$ diantaranya mengalami gagal panen. Hal tersebut dikarenakan adanya serangan hama wereng batang cokelat dan penyakit kerdil. Beberapa kali mengalami kegagalan, petani di Desa Wanguk, Kecamatan Anjatan berhasil mengurangi tingkat kegagalan panen yang terjadi setelah mendapatkan bantuan program Budidaya Tanaman Sehat (BTS) dari Direktorat Jenderal Tanaman Pangan Kementrian Pertanian RI yang diajukan oleh pemerintah setempat. Lokasi Kabupaten Indramayu yang terletak di dataran rendah dan pesisir pantai menyebabkan temperatur yang tinggi dan ketersediaan air sulit didapat. Perubahan iklim juga menyebabkan para petani kesulitan menentukan awal musim tanam 
DAMPAK PERUBAHAN IKLIM TERHADAP USAHATANI PADI

DI DESA WANGUK KECAMATAN ANJATAN KABUPATEN INDRAMAYU

Getmi Nuraisah, Rani Andriani Budi Kusumo

sehingga sering terjadi keterlambatan masa tanam. Isu perubahan iklim bukan merupakan hal yang baru. Namun, sebagian besar petani dan masyarakat pedesaan belum menyadari kondisi tersebut. Dalam kondisi seperti ini, adaptasi petani sangat diperlukan. Adaptasi terhadap perubahan iklim adalah kemampuan suatu sistem menyesuaikan diri dari perubahan iklim (termasuk di dalamnya variabilitas iklim dan variabilitas ekstrim) dengan cara mengurangi kerusakan yang ditimbulkan, mengambil manfaat atau mengatasi perubahan dengan segala akibatnya. Dengan demikian adaptasi terhadap perubahan iklim merupakan strategi yang diperlukan pada semua skala untuk meringankan usaha mitigasi dampak perubahan iklim yang terjadi (Murdiyarso, 2003). Oleh sebab itu, pengetahuan, pengalaman dan pemahaman petani terhadap perubahan iklim sangat dibutuhkan agar petani mampu beradaptasi dengan perubahan iklim yang sewaktu-waktu dapat terjadi untuk mencegah dampak yang ditimbulkan oleh perubahan iklim tersebut.

\section{METODE PENELITIAN}

Objek dalam penelitian ini adalah pengetahuan petani padi terhadap perubahan iklim dan dampak perubahan iklim terhadap pertanian serta strategi yang dilakukan petani untuk menanggulanginya. Penelitian ini dilakukan di Kecamatan Anjatan, Kabupaten Indramayu. Penentuan lokasi dilakukan secara sengaja (purposive) dengan pertimbangan pada beberapa musim tanam lalu banyak tanaman padi di Kecamatan tersebut mengalami gagal panen akibat terserang hama wereng dan penyakit kerdil yang dipengaruhi oleh cuaca yang mendukung tersebarnya hama dan penyakit tersebut, akan tetapi pada musim tanam selanjutnya, para petani di Kecamaan Anjatan melakukan beberapa perlakuan sehingga serangan hama berkurang. Penelitian ini dilakukan dengan menggunakan desain kualitatif dengan teknik studi kasus, dengan menggunakan data primer dan sekunder. Penentuan informan dilakukan secara purposif yaitu petani yang telah melakukan usahatani \pm selama 10 tahun yang mengalami gagal panen dan yang tidak dengan status kepemilikan lahan mereka. Teknik pengumpulan data yang digunakan berupa observasi, wawancara dan studi literatur. Rancangan analisis data menggunakan analisis deskriptif. 


\section{HASIL DAN PEMBAHASAN}

\section{Keadaan Umum Lokasi Penelitian}

Desa Wanguk merupakan desa yang berada di wilayah administrasi Kecamatan Anjatan, Kabupaten Indramayu; termasuk ke dalam dataran rendah, dengan ketinggian 21 meter di atas permukaan laut dengan kemiringan $<15 \%$, dan memiliki suhu berkisar antara $29-30^{\circ} \mathrm{C}$

\section{Karakteristik Petani}

Umur

Berdasarkan kelompok umur produktif, yaitu mulai umur 15-64 tahun, maka dapat diketahui bahwa sebagian besar petani termasuk ke dalam usia produktif, dimana rata-rata usianya adalah 50 tahun dengan usia termuda 38 tahun dan usia tertua 64 tahun. Dari data tersebut dapat disimpulkan bahwa kebanyakan orang yang bekerja sebagai petani adalah mereka yang berusia di atas 35 tahun.

\section{Pendidikan}

Tingkat pendidikan petani di Desa Wanguk masih tergolong rendah, hal ini ditunjukkan oleh banyaknya informan yang memiliki pendidikan terakhir SD sebanyak 4 orang atau sebesar 50\%, pendidikan terakhir SMP sebanyak 2 oarang atau $25 \%$, dan sisanya adalah petani dengan pendidikan terakhir SMA sebanyak 2 orang atau hanya $25 \%$ dari seluruh total informan. Pendidikan adalah salah satu upaya untuk meningkatkan kesejahteraan masyarakat. Semakin tinggi pendidikannya, maka semakin besar peluang untuk mendapatkan penghasilan yang lebih besar untuk memenuhi kebutuhan anggota keluarganya.

\section{Luas lahan dan status kepemilikan lahan}

Dari hasil penelitian diketahui bahwa petani memiliki luas lahan yang bervariasi yaitu 1-6 hektar. Luas lahan yang dimiliki petani mendominasi pada luas lahan 2,5-5 hektar, yaitu sebesar $62,5 \%$ atau sebanyak 5 orang petani, sedangkan petani yang memiliki luas lahan lebih dari 5 hektar sebesar 2,5\% atau hanya 1 orang petani saja, dan petani yang memiliki luas lahan 1 hektar sebesar $25 \%$ atau sebanyak 2 orang dari total informan. Rata-rata petani memiliki luas lahan sebesar 3 hektar, sehingga dapat disimpulkan bahwa petani di Desa Wanguk tergolong ke dalam petani besar karena sebagian besar petani memiliki luas lahan di atas 0,5 hektar. Status informan terhadap kepemilikan lahan di Desa Wanguk pada umumnya berstatus sebagai pemilik penggarap, yaitu sebesar $87,5 \%$ atau sebanyak 7 petani, sedangkan 
DAMPAK PERUBAHAN IKLIM TERHADAP USAHATANI PADI

DI DESA WANGUK KECAMATAN ANJATAN KABUPATEN INDRAMAYU

Getmi Nuraisah, Rani Andriani Budi Kusumo

status sebagai petani penggarap hanya sebesar $12,5 \%$ atau sebanyak 1 orang dari total petani yang dijadikan informan.

\section{Pengalaman berusahatani}

Dalam bidang pertanian jika pengalaman petani dalam bertani diperoleh sejak ia kecil, maka pengalaman dan pengetahuan bertaninya akan semakin baik. Semakin tua atau semakin lama petani melakukan usahataninya, maka petani juga akan semakin matang sehingga semakin kaya pula pengalaman dan pengetahuannya (Suprayogo, 2007). Dalam penelitian ini, pada umumnya petani berusahatani dalam kurun waktu yang cukup lama. Hal ini ditunjukkan dengan mayoritas pengalaman berusahatani petani lebih dari 10 tahun. Ini menunjukkan bahwa petani sudah cukup berpengalaman dalam melakukan usahatani.

\section{Pengetahuan Petani Terhadap Perubahan Iklim \\ Pengetahuan petani terhadap}

Dari hasil penelitian, diketahui bahwa 7 orang petani yang mengalami gagal panen dan 1 orang petani yang berhasil panen menyatakan bahwa mereka mengetahui tentang perubahan iklim, akan tetapi mereka tidak dapat menjelaskan secara rinci apa yang dimaksud dengan perubahan iklim itu sendiri. Pada umumnya mereka mengartikan perubahan iklim sebagai musim pancaroba.

\section{Perubahan masa tanam}

Dari hasil penelitian ketahui bahwa ada 6 orang petani yang menyatakan bahwa mereka mengalami perubahan atau pergeseran masa tanam, yaitu waktu tanam yang rata-rata menjadi lebih maju dari waktu yang biasanya. Sedangkan 2 orang petani menyatakan bahwa mereka tidak mengalami perubahan masa tanam.

Tabel 1. Kalender Tanam Petani

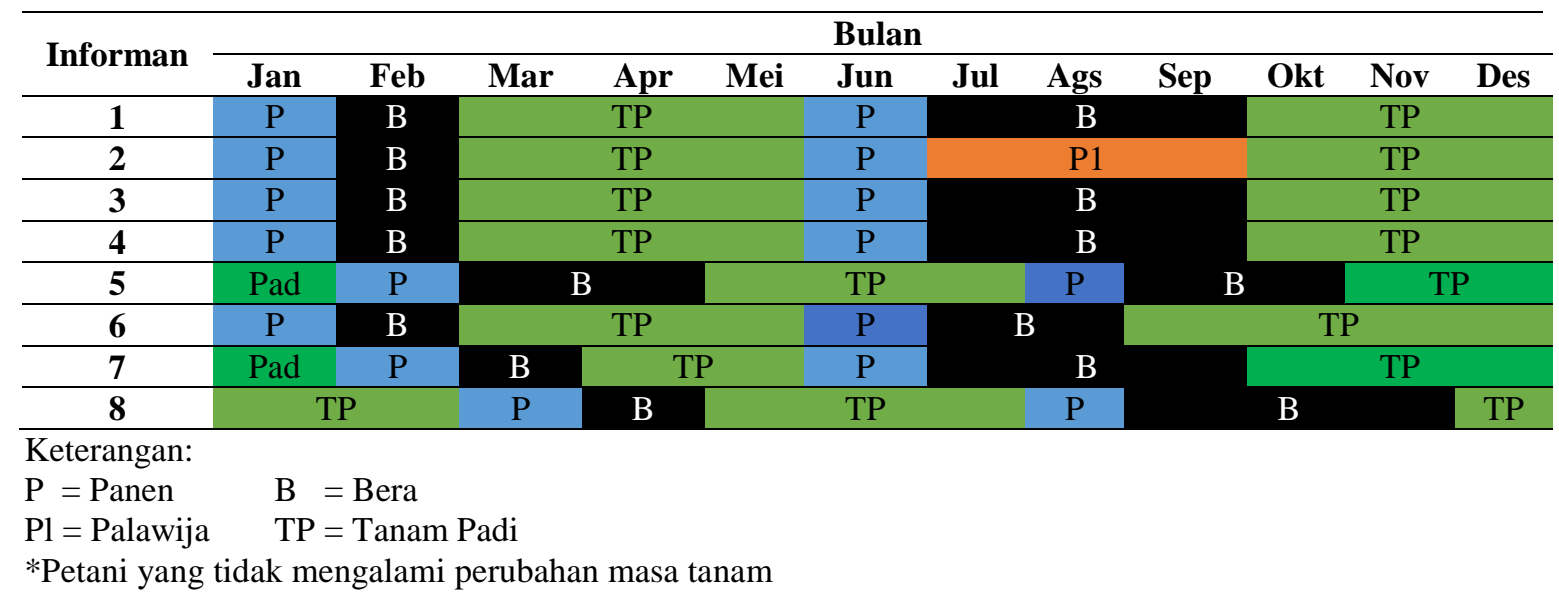


Berdasarkan hasil wawancara dengan 8 petani disebutkan bahwasanya karena melihat petani lain yang melakukan tanam pada musim tanam normal atau lebih maju yang masih berisiko mengalami kegagalan panen yang cukup besar, maka beliau mencoba untuk melakukan penanaman pada bulan Desember yaitu mundur 1 bulan dari biasanya. Ternyata dengan mengubah awal masa tanamnya petani tersebut berhasil panen, walaupun hasilnya tidak sebanyak ketika musim tanam sebelumsebelumnya. Menurut Bapak Ito, pengelola Jasa Tirta Kecamatan Anjatan, bahwa bulan Desember diprediksi bulan yang tepat untuk memulai awal musim tanam sebab intensitas hujan sudah mencapai $109 \mathrm{~mm}$, sedangkan pada bulan Oktober intensitas hujan hanya $46 \mathrm{~mm}$ dan bulan November intensitas hujan hanya $20 \mathrm{~mm}$. Selain menyangkut ketersediaan air, pengukuran curah hujan juga menyangkut kesiapan tanaman padi dalam menghadapi serangan hama.

\section{Perubahan suhu}

Dampak perubahan suhu terhadap tanaman pangan menurut Las (2007) adalah terjadinya transpirasi yang menurunkan produktivitas, peningkatan konsumsi air, percepatan pematangan buah/biji yang menurunkan mutu hasil, dan menyebabkan perkembangan beberapa OPT. Berdasarkan hasil penelitian diketahui bahwa $100 \%$ petani merasakan adanya perubahan suhu yang semakin menghangat. Hal tersebut senada dengan yang diutarakan oleh petani bahwasanya suhu yang berubah-ubah dapat memicu terjadinya serangan hama dan penyakit yang tidak menentu pula bagi tanaman.

\section{Perubahan curah hujan}

Berdasarkan data dari POJ Kecamatan Anjatan, jumlah hari hujan dan curah hujan pada tahun sebelumnya menunjukkan hasil rata-rata yang sama, yang berarti tidak adanya peningkatan hari hujan dan curah hujan di Kecamatan Anjatan. Namun, lain halnya dengan pendapat petani yang menyimpulkan bahwa musim hujan pada masa tanam tahun 2017 lebih sering dibandingkan dengan musim hujan sebelumnya.

\section{Cuaca ekstrim dan serangan OPT}

Berdasarkan hasil wawancara dengan petani di lapangan mengenai adanya kaitan antara cuaca ekstrim dengan kondisi pertanian di daerah penelitian pada saat ini, $100 \%$ petani menyatakan bahwa ada keterkaitan antara cuaca ekstrim dengan dampaknya terhadap pertanian. Faktor lain yang mempengaruhi meningkatnya serangan 
DAMPAK PERUBAHAN IKLIM TERHADAP USAHATANI PADI

DI DESA WANGUK KECAMATAN ANJATAN KABUPATEN INDRAMAYU

Getmi Nuraisah, Rani Andriani Budi Kusumo

OPT adalah suhu dan kelembaban udara.

Akibat suhu dan kelembaban udara yang semakin meningkat, akan memicu pertumbuhan dan perkembangan organisme pengganggu tanaman. Salah satunya adalah serangan hama wereng cokelat yang sempat terjadi di Desa Wanguk. Berdasarkan pengamatan dari instansi pertanian, hama wereng dapat menyebarkan virus atau penyakit kerdil rumput yang dapat menyebabkan petani mengalami kerugian bahkan gagal panen. Selain itu,, ada beberapa jenis hama yang muncul akibat adanya perubahan iklim dan menyerang tanaman padi yaitu tikus dan tungro.

\section{Dampak Perubahan Iklim Terhadap Sektor Pertanian}

\section{Penurunan produksi}

Pada sektor pertanian, konsep risiko dapat diartikan sebagai suatu kemungkinan yang dapat menyebabkan kerugian yang diwakili oleh penurunan produksi tanaman pangan. Bahaya penurunan produksi ini dapat mengakibatkan secara langsung maupun tidak langsung terhadap penurunan kesejahteraan petani serta penurunan pasokan pangan di suatu wilayah (Ruminta, 2016).

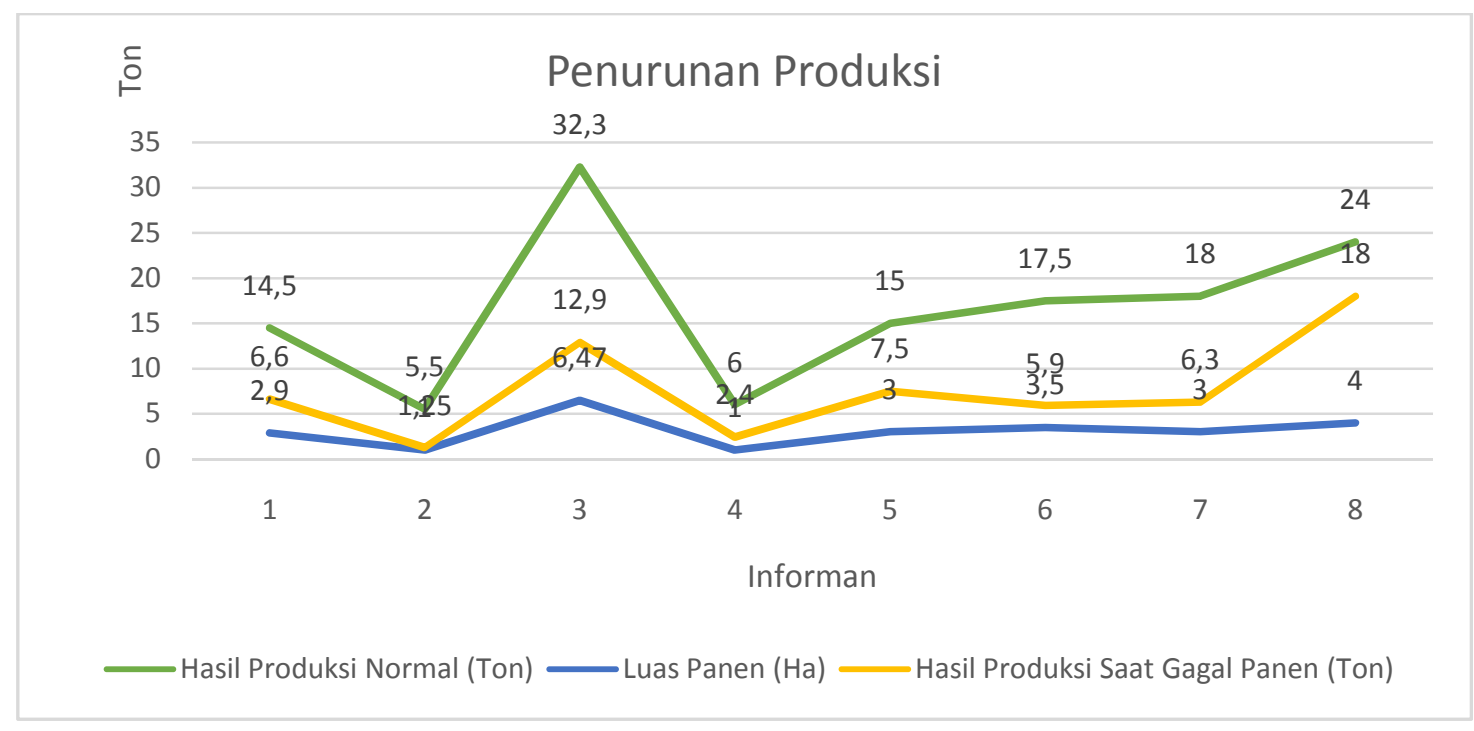

\section{Gambar 1. Penurunan Produksi Padi}

Menurut hasil penelitian dan wawancara di lapangan, petani menyatakan bahwa biasanya rata-rata produksi gabah yang mereka dapat ketika normal sebanyak 6-8 ton per hektar, akan tetapi ketika gagal panen mereka hanya mendapat beberapa ton saja bahkan ada yang mendapatkan beberapa kwintal. 
Dapat disimpulkan bahwa perubahan iklim membawa dampak yang cukup besar bagi pertanian terlebih bagi petani yang menjalankan usahatani padi di Desa Wanguk sebab mereka mengalami penurunan produksi rata-rata hingga $50 \%$ dari hasil normal ketika panen. Mayoritas kegagalan panen yang dialami oleh petani disebabkan karena intensitas serangan wereng batang cokelat yang tinggi, penyakit kerdil rumput (klowor) dan tingginya intensitas hujan pada musim tanam tersebut.

\section{Peningkatan serangan OPT}

Berdasarkan hasil penelitian, peningkatan serangan OPT di wilayah Indramayu khususnya di Desa Wanguk sendiri cukup membuat petani kewalahan. Pasalnya lebih dari 50\% lahan mereka mengalami gagal panen akibat adanya serangan OPT yang berlebihan.
OPT yang menyerang lahan pertanian petani di Desa Wanguk adalah WBC (wereng batang cokelat) dan penyakit kerdil rumput atau yang biasa disebut oleh petani Indramayu dengan penyakit klowor. Serangan OPT yang menyerang lahan petani luasannya berbeda-beda. Pengaruh suhu yang tinggi yaitu antara $26-33^{\circ} \mathrm{C}$ dan kelembaban/RH antara $70,5-81,0 \%$ serta cuaca yang tidak menentu yang terjadi di Indramayu menjadi salah satu pemicu terjadinya ledakan hama dan penyakit tersebut. Berdasarkan hasil wawancara dengan petani, mayoritas dari petani menyatakan bahwa selama musim tanam pada tahun 2017 adalah musim paceklik, sebab mayoritas dari petani mengalami gagal panen yang cukup parah bahkan tidak menghasilkan padi sama sekali.

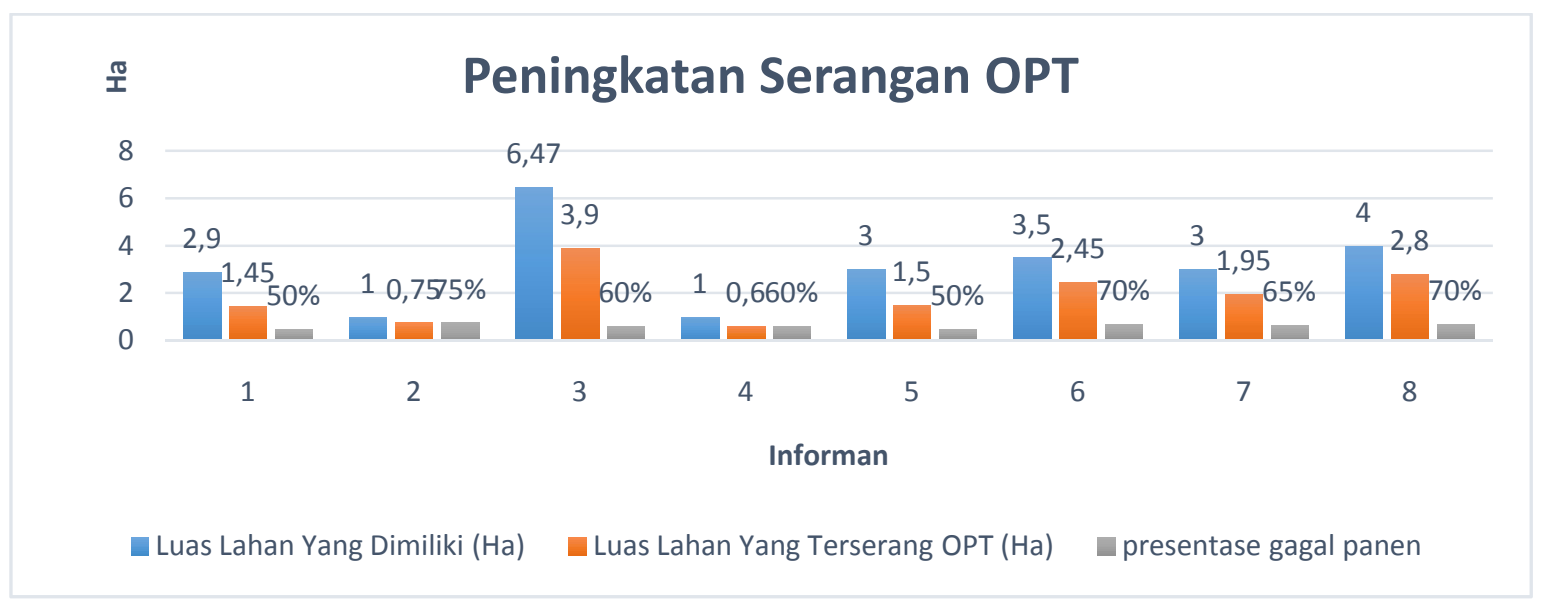

Gambar 2. Peningkatan Serangan OPT Akibat Perubahan Iklim 
DAMPAK PERUBAHAN IKLIM TERHADAP USAHATANI PADI

DI DESA WANGUK KECAMATAN ANJATAN KABUPATEN INDRAMAYU

Getmi Nuraisah, Rani Andriani Budi Kusumo

Risiko gagal panen dan penurunan pendapatan

Perubahan iklim dapat berdampak negatif karena dapat menyebabkan penurunan kualitas, peningkatan serangan OPT, gagal panen dan penurunan pendapatan, sehingga dapat menyebabkan penurunan tingkat kesejahteraan petani. Perubahan iklim dapat berdampak pada ketersediaan air dan memicu ledakan serangan hama dan penyakit (Wiyono, 2010). Dalam penelitian ini ditemukan bahwa rata-rata luas lahan petani yang mengalami gagal panen seluas > 1 hektar. Oleh sebab itu, risiko gagal panen yang dihadapi petani itu tinggi (75\%). Dalam penelitian ini risiko terbesar petani adalah gagal panen, sebab dari hasil pertanian lah mereka dapat menafkahi keluarga. Ketika mengalami gagal panen secara otomatis petani juga mengalami penurunan pendapatan. Penghasilan yang rendah dari hasil pertanian mendorong petani untuk mencari alternatif tambahan penghasilan guna memenuhi kebutuhan keluarganya. Upaya yang dilakukan petani salah satunya adalah menjalani pola nafkah ganda (Sumarti, 2007 dalam Sugiharto, 2016).

Tabel 2. Risiko Gagal Panen Akibat Ari Dampak Perubahan Iklim

\begin{tabular}{cccc}
\hline Informan & Luas lahan yang dimiliki & Luas lahan yang terserang OPT & Persentase $(\%)$ \\
\hline 1 & 2,9 ha & $1,45 \mathrm{ha}$ & 50 \\
2 & $1 \mathrm{ha}$ & $0,75 \mathrm{ha}$ & 75 \\
3 & $6,47 \mathrm{Ha}$ & $3,9 \mathrm{ha}$ & 60 \\
4 & $1 \mathrm{ha}$ & $0,6 \mathrm{ha}$ & 60 \\
5 & $3 \mathrm{ha}$ & $1,5 \mathrm{ha}$ & 50 \\
6 & $3,5 \mathrm{ha}$ & $2,45 \mathrm{ha}$ & 70 \\
7 & $3 \mathrm{ha}$ & $1,95 \mathrm{ha}$ & 65 \\
8 & $4 \mathrm{ha}$ & $2,8 \mathrm{ha}$ & 70 \\
\hline
\end{tabular}

\section{Penurunan pendapatan}

Menurut Soekartawi

(1995), penerimaan usahatani merupakan perkalian antara produksi dengan harga jual. Nilai uang yang diterima dari penjualan produk ushatani disebut penerimaan usahatani, sedangkan biaya usahatani adalah semua pengeluaran yang dipergunakan dalam suatu usahatani. Penghasilan yang rendah dari hasil pertanian mendorong petani untuk mencari alternafif tambahan penghasilan guna memenuhi kebutuhan keluarganya. Upaya yang dilakukan petani salah satunya adalah menjalani pola nafkah ganda (Sumarti, 2007 dalam Sugiharto, 2016). Berdasarkan Gambar 3 dapat disimpulkan bahwa pada saat gagal panen petani mengalami kerugian yang cukup besar. Sebagian besar petani mensiasati 
kebutuhan keluarga mereka dengan mengandalkan pekerjaan lain seperti berdagang atau beternak. Berdasarkan hasil penelitian, dapat diketahui bahwasanya pada musim tanam tahun
2017 lalu, petani mengalami kerugian yang besar. Hal tersebut dapat dilihat pada Gambar 3 bahwa pendapatan petani pada satu musim tanam menurun drastis akibat gagal panen yang terjadi.

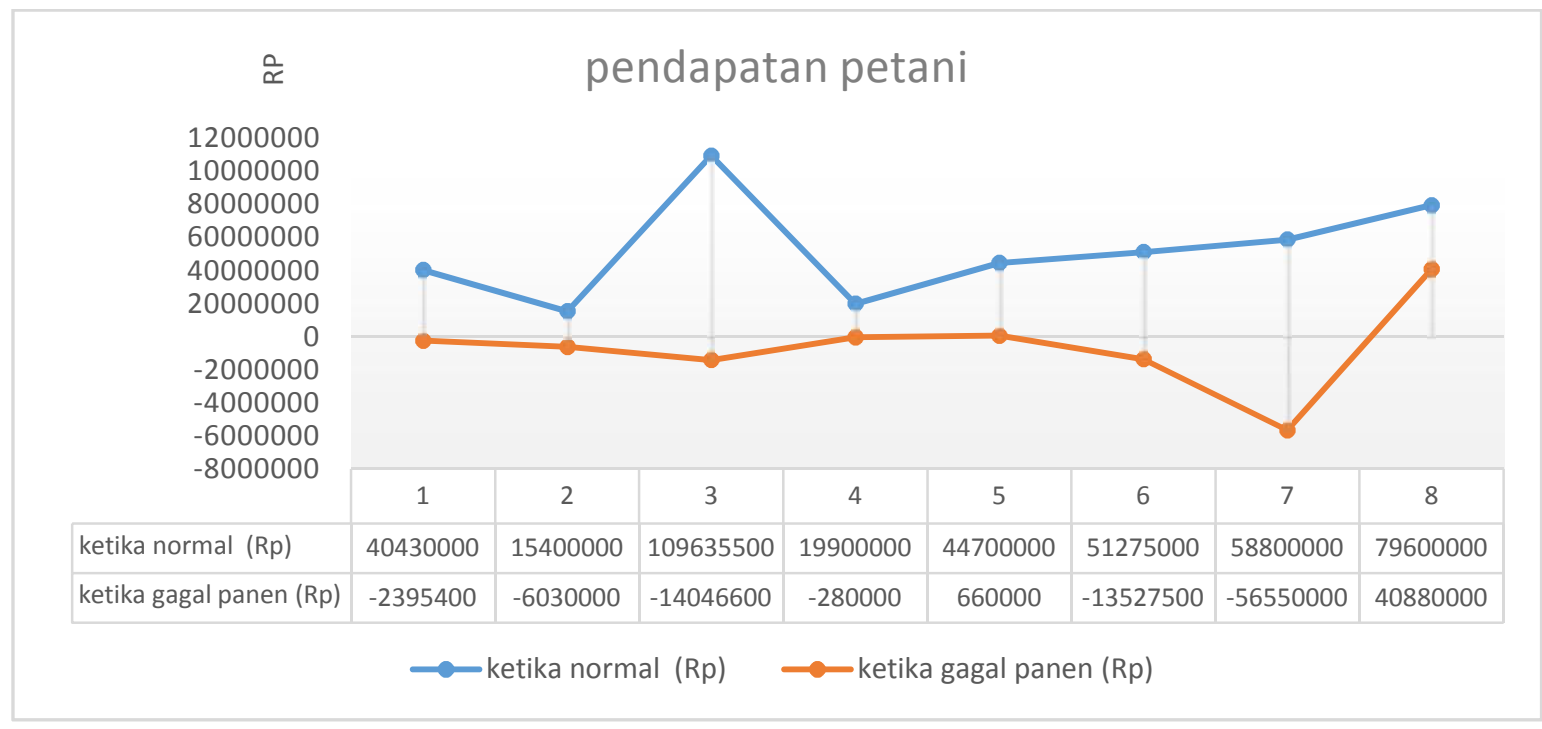

Gambar 3. Penurunan Pendapatan Petani

\section{KESIMPULAN DAN SARAN}

\section{Kesimpulan}

1. Petani sudah sepenuhnya mengetahui dan merasakan perubahan-perubahan yang terjadi terkait perubahan iklim seperti perubahan masa tanam, perubahan suhu, perubahan curah hujan, cuaca ekstrim berupa perubahan hari hujan, hujan angin, suhu yang semakin menghangat, dan serangan, akan tetapi petani tidak dapat menjelaskan secara rinci apa perubahan iklim itu sendiri.

2. Dampak yang dirasakan petani akibat dari perubahan iklim yang terjadi antara lain petani mengalami penurunan hasil panen, semakin meningkatnya serangan OPT akibat ketidakpastian cuaca, terjadinya peningkatan risiko gagal panen dan penurunan pendapatan petani.

\section{Saran}

1. Perlu adanya pemahaman yang baik terhadap konsep perubahan iklim, salah satunya dengan pelatihan Sekolah Lapang Iklim (SLI) dan penyampaian informasi melalui kegiatan penyuluhan. 
2. Untuk menghindari dampak terburuk dari perubahan iklim, seluruh pihak, baik petani, aparat desa, pemerintah atau instansi yang terkait harus lebih meningkatkan kerjasama dan komunikasi mengenai semua hal yang berkaitan dengan strategi antisipasi, mitigasi dan adaptasi yang harus dklakukan, serta melakukan pengontrolan akan strategi tersebut.

\section{DAFTAR PUSTAKA}

Estiningtyas, W., Boer, R., Las, I., \& Buono, A. 2012. Identifikasi dan Delineasi Wilayah Endemik Kekeringan Untuk Pengelolaan Risiko Iklim di Kabupaten Indramayu. Jurnal Metodologi dan Geofisika, 13(1): 9-20.

Eukarista, M.T. 2015. Peran SDM dalam Meningkatkan Aktivitas Kelompok Tani di Desa Tember. Ejournal"Acta Diurna", 4(3).

Hakim, L., dan Sugihen, B. G. 2015. Keberdayaan Petani Sayuran dalam Mengakses Informasi Pertanian di Sulawesi Selatan. Jurnal Penyuluhan, 5(1).

Japa, L., Raksun, A., Karnan, K., \& Santoso, D. 2018. Implementasi Biofermentasi "Effective Microorganism" dalam Pengolahan Sampah Pertanian dan Peternakan Untuk Meningkatkan Pertumbuhan Tanaman. Jurnal Pendidikan dan Pengabdian Masyarakat, 1(1): 111115.

Las, Irsal. 2007. Strategi dan Inovasi Antisipasi Perubahan Iklim. Balai Besar Sumberdaya Lahan Pertanian. Jakarta.
Murdiyarso, D. 2003. Sepuluh Tahun Perjalanan Negosiasi Konvensi Perubahan Iklim. Jakarta: Kompas.

Rasmikayati, E., \& Djuwendah, E. 2015. Dampak Perubahan Iklim Terhadap Perilaku dan Pendapatan Petani (The Impact of Climate Change to Farmers' Behavior and Revenue). Jurnal Manusia dan Lingkungan, 22(3): 372-379.

Ratag, M. 2007. Perubahan Iklim: Perubahan Variasi Curah Hujan, Cuaca, dan Iklim Ekstrim. Jakarta: Badan Meteorologi dan Geofisika: 2 Maret 2007.

Salikin, K. A. 2003. Sistem Pertanian Berkelanjutan. Yogyakarta: Kanisius.

Soekartawi. 1995. Analisis Usahatani. Jakarta: UI Press

Sudaryanto, T., \& Rusastra, I.W. 2006. Kebijakan Strategis Usaha Pertanian Dalam Rangka Peningkatan Produksi dan Pengentasan Kemiskinan. Jurnal Litbang Pertanian, 25(4): 115-122.

Sugiharto, A., Hartoyo, H., dan Muflikhati, I. 2016. Strategi Nafkah dan Kesejahteraan Keluarga pada Keluarga Petani Tadah Hujan. Jurnal Ilmu Keluarga dan Konsumen, 9(1): 33-42.

Syahza, A. (2003). Paradigma Baru Pemasaran Produk Pertanian Berbasis Agribisnis di Daerah Riau. Jurnal Ekonomi, 8(1), 1-11.

Wiyono, S. 2010. Perubahan Iklim dan Ledakan Hama dan Penyakit Tanaman. Seminar Sehari Tentang Keanekaragaman Hayati di Tengah Perubahan Iklim. Institut Pertanian Bogor. pp. 1-10. 